\section{(6) OPEN ACCESS}

${ }^{1}$ Renal Unit, Aberdeen Royal Infirmary, Aberdeen, UK

${ }^{2} \mathrm{NHS}$ Grampian, Aberdeen, Aberdeen, UK

Correspondence to

Dr El Hakem Abdelkarim Metraiah,

metraiah@gmail.com

Accepted 12 January 2017

\title{
Deceiving proteins! A case of lymphoma and high creatinine
}

\author{
El Hakem Abdelkarim Metraiah, ${ }^{1}$ Helen Regan, ${ }^{2}$ Johanna Louw, ${ }^{1}$ Dana Kidder ${ }^{1}$
}

\begin{abstract}
SUMMARY
Estimation of kidney function by measuring serum creatinine is one the commonest laboratory tests conducted in clinical practice. Enzymatic methods are often used to measure serum creatinine. Clinicians should be aware of the limitations of these methods, such as test interference with paraproteins.We present a case of falsely elevated serum creatinine in a patient referred for renal biopsy. The combination of fluctuating creatinine and normal blood urea level was unusual. Serum protein electrophoresis revealed the presence of an IgM paraprotein. Further investigations confirmed an underlying diagnosis of lymphoplasmacytoid lymphoma. This case highlights how IgM paraprotein can interfere with creatinine estimation by enzymatic assay and the utility of alternative methods of estimating serum creatinine.
\end{abstract}

\section{BACKGROUND}

It is important to question the validity of the test used if results are inconsistent or conflicting with clinical and other laboratory findings.

Clinicians should be familiar with the method used to measure serum creatinine at their local laboratory and should be aware of alternative tests to measure kidney function. Jaffé method which is based on reaction of creatinine with picric acid is a commonly used for creatinine measurement but large number of substances can interfere with this method including bilirubin, acetoacetate and various drugs. ${ }^{1}$

Newer enzymatic tests such as Siemens Advia enzymatic assay are thought to be more specific but they are also subject to interference as we demonstrated in this case, also here, unravelling the cause of test interference helped towards making the right diagnosis.

\section{CASE PRESENTATION}

A 62-year-old woman presented to her general practitioner with fatigue, headache and itching over a period of 6 weeks. There was no history of fever, jaundice or weight loss. She was treated for otitis externa with erythromycin 2 weeks before her presentation. Routine bloods tests showed elevated serum creatinine at $285 \mu \mathrm{mol} / \mathrm{L}$ (estimated glomerular filtration rate (eGFR) $16 \mathrm{~mL} / \mathrm{min} / 1.73 \mathrm{~m}^{2}$ ). Her serum creatinine was $56 \mu \mathrm{mol} / \mathrm{L}$ (eGFR $>60 \mathrm{~mL} / \mathrm{min} / 1.73 \mathrm{~m}^{2}$ ) 5 months prior to her presentation, for summary of her laboratory investigations see table 1 .

Medical history included: hypertension, anxiety, depression, hysterectomy, cholecystectomy and herpes zoster infection. Her medications included: hormonal replacement patches, bendroflumethiazide $2.5 \mathrm{mg}$ once daily and venlafaxine $75 \mathrm{mg}$ once daily. She was a non-smoker and her alcohol consumption was $<2$ units per week.

\section{INVESTIGATIONS}

The patient was admitted to the renal unit for further assessment and consideration of performing a renal biopsy. Abdominal examination revealed splenomegaly. There was no evidence of generalised lymphadenopathy.

The urine dipstick was bland on multiple occasions. Chest X-ray was normal. Abdominal ultrasound confirmed splenomegaly $(17 \mathrm{~cm})$ with normal-size kidneys. Serum protein electrophoresis and immunofixation showed IgM band at a level of $8.58 \mathrm{~g} / \mathrm{L}$ (normal range $0.5-3 \mathrm{~g} / \mathrm{L}$ ).

A significant degree of fluctuation in serum creatinine was noted following her hospitalisation (figure 1).

This fluctuating pattern along with normal urea concentration raised suspicion about the validity of serum creatinine measurement particularly with the presence of paraproteinaemia.

To investigate this possibility further, serum creatinine was measured using the picric acid Jaffé method. Renal excretory function was also assessed with Cr51 EDTA isotope GFR measurement. Serum creatinine concentration was found to be $86 \mu \mathrm{mol} / \mathrm{L}$ by the Jaffé method and it was consistent with the Cr51 EDTA GFR result of $71 \mathrm{~mL} / \mathrm{min}$ (table 2).

Taken together, these findings indicated that serum creatinine was falsely elevated when measured with enzymatic assay due to the presence of an interfering compound. IgM paraprotein was the culprit substance in this case.

A bone marrow biopsy was performed and the histology and immunohistochemistry findings were in keeping with a diagnosis of low-grade B-cell non-Hodgkin's lymphoma.

\section{TREATMENT, OUTCOME AND FOLLOW-UP}

Patient was treated initially with combination of rituximab and bendamustine. She developed an allergic reaction to rituximab. She eventually completed five cycles of bendamustine with good response. Postchemotherapy serum creatinine returned to normal range, which also coincides with paraprotein disappearance (figure 1).

\section{DISCUSSION}

It is important that clinicians are aware of limitations of commonly used laboratory tests. Such 
Table 1 Patient laboratory results with corresponding reference interval

\begin{tabular}{lll}
\hline Investigation & Result & Reference \\
\hline Leukocytes (109/L) & 6.4 & $4-10$ \\
Haemoglobin (g/L) & 101 & $13-17$ \\
Erythrocyte cell volume (MCV) & 92 & $82-99$ \\
Platelets (10 $/ \mathrm{L})$ & 225 & $140-400$ \\
Sodium (mmo//L) & 133 & $133-146$ \\
Potassium (mmol/L) & 3.5 & $3.5-4.8$ \\
Phosphate (mmo//L) & 1.26 & $0.8-1.5$ \\
Urate (vmol/L) & $<30$ & $140-360$ \\
Protein total (g/L) & 72 & $60-80$ \\
Albumin (g/L) & 36 & $35-50$ \\
IgA (g/L) & 1.97 & $0.8-4.0$ \\
IgM (g/L) & 8.58 & $0.5-3.0$ \\
IgG (g/L) & 5.69 & $6.0-16$ \\
Paraprotein type & $1 g M$ lambda \\
C3 (mg/dL) & 112.0 & $90-180$ \\
C4 (mg/dL) & $<1.7$ & $10-40$ \\
C reactive protein (mg/dL) & 40 & $0-4$ \\
ANA & Negative & \\
ANCA & & \\
Anti-MPO (IU/mL) & $<0.1$ & Normal: $0.0-3.5$ \\
Anti-PR3 (IU/mL) & 0.2 & Normal: $0.0-2.0$ \\
Anti-GBM (U/mL) & 1.0 & Negative $<7$ \\
\hline ANA, anti-nuclear antibody; ANCA, anti-neutrophil cytoplasmic antibody; anti-GBM, \\
anti-glomerular basement membrane antibodies; anti-MPO, myeloperoxidase \\
antibodies; anti-PR3, anti-proteinase 3 antibodies. \\
\end{tabular}

knowledge aids in avoiding unnecessary and potentially invasive investigation. In the UK, $\sim 25 \%$ of laboratories use an enzymatic method to measure creatinine. In general, the enzymatic method, although more expensive, is preferred over the kinetic Jaffé assay as it is less affected by interferences such as bilirubin, protein, glucose and ketones. ${ }^{1}$ However, in this case, we demonstrate how an enzymatic creatinine method was subject to interference by IgM paraproteinaemia.
Table 2 Results obtained by three different methods arranged over 48 hours

\begin{tabular}{lll}
\hline Method used & Serum creatinine $(\boldsymbol{\mu m o l} / \mathrm{L})$ & eGFR \\
\hline Siemens Advia enzymatic assay & 412 & 10 \\
Jaffé method & 86 & $>60$ \\
Cr51 EDTA & GFR $71 \mathrm{~mL} / \mathrm{min}$ & \\
\hline eGFR, estimated glomerular filtration rate.
\end{tabular}

Paraproteins have been shown to artificially influence different methodologies of automated assays, including nephelometry, turbidimetry and immunoassays. ${ }^{2} 3$

Reports in the literature highlight cases where paraproteins have been shown to interfere with various assays available on the automated analysers, including calcium, bilirubin, chloride, phosphate and glucose. ${ }^{3}$

In one case report, IgM test interference was observed using Siemens Advia enzymatic assay but not Abbott Architect method. ${ }^{4}$ Both assays are using similar enzymatic reactions but differ in methods of hydrogen peroxide and chromogen detection.

The mechanism behind this $\operatorname{IgM}$ paraprotein interference is unclear.

Scott et al suggested that interference phenomenon might depend on the variable region of the IgM monoclonal antibody. Using Roche creatinine plus enzymatic method, they reported that only one in five patients with $\operatorname{IgM}$ paraproteinaemia showed a falsely elevated serum creatinine. ${ }^{5}$ An alternative explanation is that the IgM paraprotein may form complexes with the reagents and increase the turbidity of the sample interfering with the absorbance measurement. ${ }^{6}$

In our case, the monoclonal IgM band associated with lymphoplasmacytoid lymphoma caused a false elevation in the serum creatinine concentration when measured by Siemens Advia enzymatic assay method. This method is based on the enzymatic reaction where creatinine is converted to creatine by the action of creatininase, to produce creatine and sarcosine.

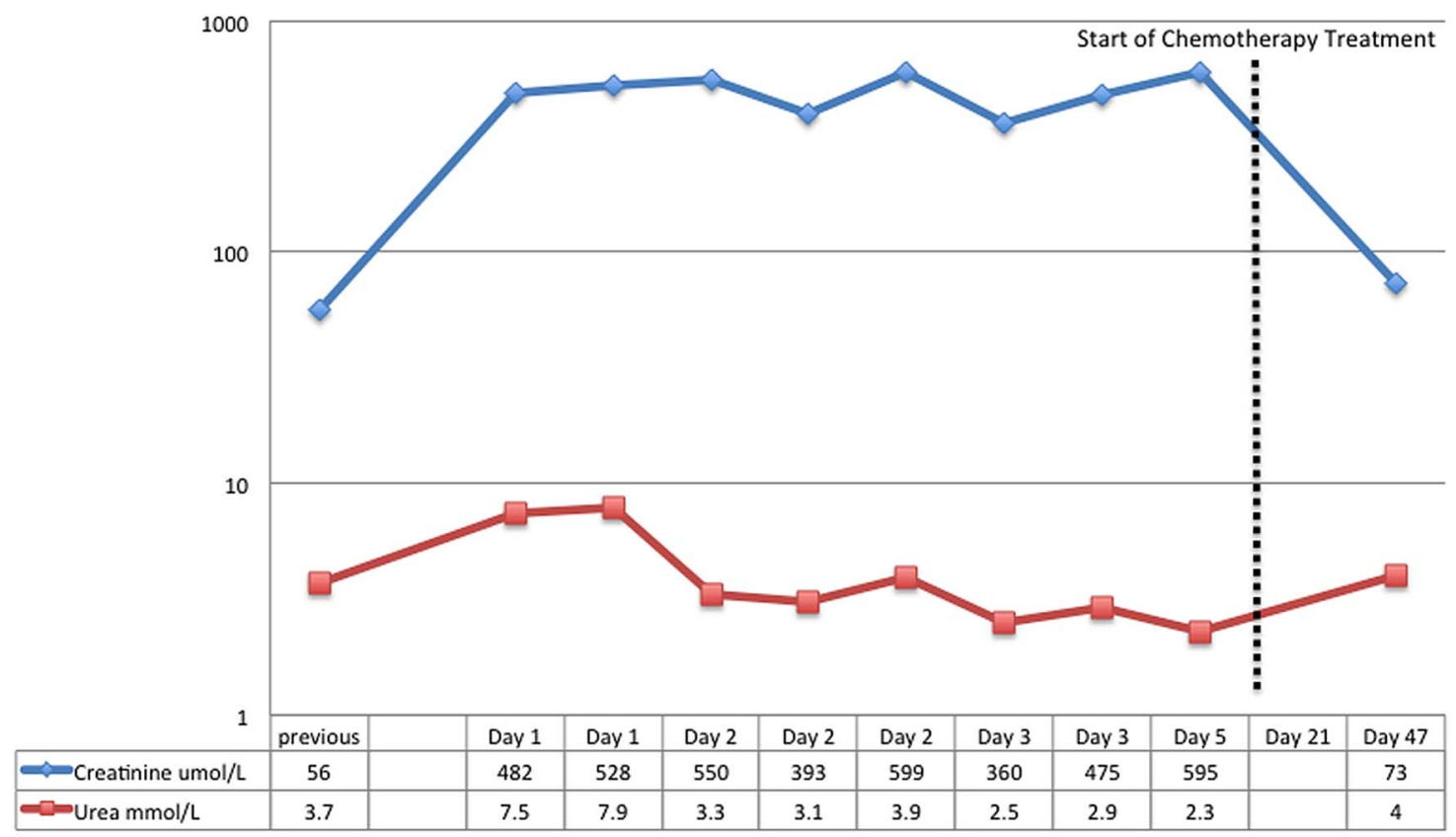

Figure 1 Plasma levels of Creatinine and urea before and after treatment. 
The sarcosine is metabolised by sarcosine oxidase to produce glycine, formaldehyde and hydrogen peroxide. The hydrogen peroxide in the presence of peroxidase yields a blue pigment. The creatinine concentration is calculated by measuring the absorbance of the blue colour at 596/694 nm.

This case highlights the significance of paraprotein interference with commonly used laboratory test. We recommend considering this possibility when assessing individual with elevated serum creatinine and detectable IgM paraprotein.

\section{Learning points}

- Paraproteinaemia should be considered as a cause of falsely elevated serum creatinine concentration.

- Validity of any test should be questioned if results are inconsistent or conflicting with the clinical condition of the patient.

- Good communication between clinicians and laboratories is crucial when investigating challenging cases like this.

Contributors E-HM is primary author and performed writing, editing and literature search. DK is senior author involved in writing, editing and supervising manuscript. HR helped in editing and case discussion. JL helped in editing.
Competing interests None declared.

\section{Patient consent Obtained.}

Provenance and peer review Not commissioned; externally peer reviewed.

Open Access This is an Open Access article distributed in accordance with the Creative Commons Attribution Non Commercial (CC BY-NC 4.0) license, which permits others to distribute, remix, adapt, build upon this work non-commercially, and license their derivative works on different terms, provided the original work is properly cited and the use is non-commercial. See: http://creativecommons.org/ licenses/by-nc/4.0/

\section{REFERENCES}

1 Greenberg N, Roberts WL, Bahmann LM, et al. Specificity characteristics of 7 commercial creatinine measurement procedures by enzymatic and Jaffe method principles. Clin Chem 2012;58:391-401.

2 Yang Y, Howanitz PJ, Howanitz JH, et al. Paraproteins are a common cause of interferences with automated chemistry methods. Arch Pathol Lab Med 2008;132:217-23.

3 Berth M, Delanghe J. Protein precipitation as a possible important pitfall in the clinical chemistry analysis of blood samples containing monoclonal immunoglobulins: 2 case reports and a review of the literature. Acta Clin Belg. 2004;59:263-73.

4 Salter T, Marsh J, Sood B, et al. Pseudohypercreatininaemia in two patients caused by monoclonal IgM interference with enzymatic assay of creatinine. J Clin Pathol 2015;68:854-5.

5 McGill MR, Vijayan A, Trulock EP, et al. Falsely elevated plasma creatinine due to an immunoglobulin M Paraprotein. Am J Kidney Dis 2016;68:789-92.

6 Hummel KM, von Ahsen N, Kuhn RB, et al. Pseudo hypercreatininemia due to positive interference in enzymatic creatinine measurements caused by monoclonal IgM in patients with Waldenstrom's macroglobulinemia. Nephron 2000;86:188-9.

Copyright 2017 BMJ Publishing Group. All rights reserved. For permission to reuse any of this content visit http://group.bmj.com/group/rights-licensing/permissions.

BMJ Case Report Fellows may re-use this article for personal use and teaching without any further permission.

Become a Fellow of BMJ Case Reports today and you can:

- Submit as many cases as you like

- Enjoy fast sympathetic peer review and rapid publication of accepted articles

- Access all the published articles

- Re-use any of the published material for personal use and teaching without further permission

For information on Institutional Fellowships contact consortiasales@bmjgroup.com

Visit casereports.bmj.com for more articles like this and to become a Fellow 